\title{
Ergonomic analysis jobs in recovered factories
}

\author{
Gabriela Cuenca ${ }^{\mathrm{a}, *}$, Gastón Zotta ${ }^{\mathrm{b}}$ and col. \\ ${ }^{a b a}$ Department of Industrial Engineering, National Technical University,(UTN), Buenos Aires, Argentina in- \\ fo@gabrielacuenca.com.ar; zgaston@gmail.com
}

\begin{abstract}
With the advent of the deep economic crisis in Argentina on 2001, the recovery of companies through to the creation of the Cooperatives Working Self-Management or Factories Recovered by its workers was constituted as one of the ways in which the salaried disobeyed the increasing unemployment.

When the companies turn into recovered factories they tend to leave of side practices that have been seen like imposed by the previous organization and not understanding them as a primary condition for the execution of his tasks.

Safety and ergonomics are two disciplines that are no longer considered relevant to the daily work. Therefore this investigation aims to revalue, undergo semantic to give back to a place in every organization analyzed.

This research developed a self-diagnostic tool for working conditions, and the environment, present in the recovered factories.
\end{abstract}

Keywords: recovered factories; self management, ergonomics, working conditions, self-diagnotics tools.

\section{Introduction}

At the beginning of the last decade, particularly since 2001, thousands of employees across the country have taken over companies going into bankruptcy, closing and/or committing major violations of their workers wage contract. Thus, self-managed enterprises were formed, "free of bosses", born of the determination to defend a labor source.

In this context we understand that the Recovered Factories require not just marketing tools and / or management but also, by optimizing the management of the organization and its working conditions, a double purpose would be achieved acting on health and comfort at work, coupled with an improvement of people's performance and of its workplace.

This research seeks to improve substantially the conditions in Recovered Factories in order to optimize health and comfort in the workplace, accident prevention, and productivity. To do so, one seeks to develop an analytical model applied for the improvement of working conditions

In addition, one expects offering them a tool in order that they could learn what the ergonomics indicators are and how to and detect them, so that they turn them into elements of continuous improvement.

So far, the published research papers concerning "Recovered Factories" rather build on a sociological approach on self-managed organizations, without deepening on an ergonomic analysis of workplaces.

\section{Objective}

This research sets up as its main goal the development of a working conditions and environment self-assessment tool, present in recovered factories.

* All authors are members of the Ergonomics Research Team. Department of Industrial Engineering, National Technical University (UTN) Buenos Aires, Argentina. Head Research: Gabriela Cuenca: info@gabrielacuenca.com.ar 


\section{Selection of the sample}

For this purpose we selected from the universe of recovered factories those that met together different features. We looked for standardizing the obtained data, gathering it in a checklist where each company - whatever its type of activity, its amount of workers and its type of product was - could be able to assess in a simple and fast way, its situation and the critical points to improve.

Work Cooperative 1: Activity: Manufacture and commercialization of vinyl fabrics, films and PVC foams.

Work Cooperative 2: Activity: Manufacture and commercialization of balloons.

\section{Methodology}

The methodology was based primarily on fieldwork and subsequent analysis of observed data. In each selected factory, one made direct observations on work stations, interviews with the involved workers, and indirect observations through sensible indirect observations provided by them, as well as a diagnosis based on what has been observed and presented recommendations.

The dimensions analyzed in each factory were: -Workers population.

- The conditions under which work was performed.

- The way work was really done (activity)

\section{5- Fieldwork}

During the field work we studied the working conditions in each selected factory (macroergonomics), we analyzed the production methods, the manufacturing processes, and the facility from an ergonomics perspective. One also interviewed workers and identified their workload.

With the information gathered, a diagnosis was done on each factory's working conditions with regard to ergonomics and occupational health and safety, to the processes and the quality of them. After the diagnosis, we developed specific recommendations to improve the facilities and the redesign of jobs for each factory.

We also made a comparative study between factories participating in the project, in order to establish the similarities between them and thus make general recommendations to improve working conditions and its environment, applicable to all Recovered Factories and to all cooperatives, small and very small companies.

These matches were the basis for creating grids of analysis that can be used by workers to know the situation of the organization in general, the specific situation of their workstation, and their own situation.

\section{6-Major similarities between the factories studied}

During the fieldwork there were some common features in these types of organizations relating to their particular form of self-management, among which are mentioned as follows:

- Do not share a value system for the workers seeking their individual welfare.

- Not kept as valid that which was accepted by the previous administration. An example of this is the "facon" production as a way to get an income cyclical low in the absence of working capital, the risk that continue over time.

- No labor discipline and trained personnel in areas of administration and sales, because the workers are mostly production.

- There is no differentiation in the remuneration received, noting that all perceived the same pay, without differentiation of knowledge, roles and seniority.

Continuing with the description of the common features observed in these organizations, a topic which until now did not seem to be the center of attention of workers, few exceptions, is the hygiene and safety.

Within the factories do not follow safety rules. They work without using the safety and regulatory components.Using them is to free choice of workers, who largely reject them because they are uncomfortable.

The lack of importance given to the working conditions are reflected in one of the factories studied, and the lack of adequate ventilation, dust workers inhale

Moreover, the dimension referred to the potential harm to their physical, paradoxically remains a relatively alien.

Despite the lack of preventive policy on job security, according to the key information provided by 
the factories, accidents seem to have fallen by the already mentioned lower labor intensity and pressure at work. However, under the control of production in general, makes it impossible to corroborate these claims as there are no systematic statistics.

\section{Results}

Based on the diagnosis and recommendations made, developed a methodology to analyze systemic problems Ergonomic Self-Managed Work Cooperatives (Factories Recovered) considered as a tool to understand first what are the conditions under which the factory is located, then what will be priority actions according to the results of the checklist used.

The following describes the software tool created for the collection of data

-Ergonomic tools used.

- Information on jobs

Also, this tool has the possibility of adding links to reference different resources such as photos and videos serve as a complement to the description, in order to integrate all the work relieved (figure1).

Thus, the application can be used by a non-expert to relieve in a systematic and orderly work environment conditions and present in your organization as well as existing physical load on each workstation, and based on different disciplines gave rise to this investigation.

-Information production processes.

-Diagram of analysis of production processes.

-Plans lay out production.

-Data related to the environment.

-Evaluation of simulated emergencies.

-Data from the organization.

-Data about the activity.

It consists of various "blades" which defines tables and / or forms that correspond to different disciplines, namely with characteristics similar to those studied in this research project.

This instrument was used to validate the transfer of the accumulated information to a more dynamic and user friendly it as input to another application in the form of refined ad hoc check list, self-administered, resulting in a weighted situational state, with associated improvement actions.
Ergonomic Computer Application Comprehensive Survey.

From the field work performed by each subteam, in the surveyed organizations, worked on the development of a software application based on Ms. Excel tool, which aims to systematize the task of initial survey an organization such as "Recovered Factory"

Thus knowing the problems and possible solutions have roads, conveys the improvement of working conditions, comfort and health of workers, consequently increasing the productivity and competitiveness.

\section{References}

[1] Guerin F, Laville A. Daniellou F. Durafourg J, Kerguelen, A. Comprender el trabajo para transformarlo, la práctica ergonómica. Modus Laborandi, Madrid, 2009.

[2] Novic Marta y col., Aportes a una nueva visión de la informalidad en la Argentina, Banco Mundial; Ministerio de Trabajo Empleo y Seguridad Social, 2008, 1era edición

[3] Ferrari,V. El caso de las empresas / fábricas recuperadas por los trabajadores: La filosofía popular. INAES: Instituto Nacional de Asociatividad y Economía Social, 2007,

[4] Rebón, J. Trabajando sin patrón. Las empresas recuperadas y la producción. Instituto de Investigaciones Gino Germani Facultad de Ciencias Sociales - UBA. 2005 